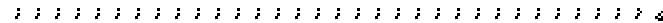

: Widya Akuntansi dan Keuangan

: Universitas Hindu Indonesia

Edisi Agustus 2020

\title{
PENGARUH PARTISIPASI MANAJEMEN DAN KEPUASAN PENGGUNA TERHADAP EFEKTIVITAS PENGGUNAAN SISTEM INFORMASI AKUNTANSI DI LPD KECAMATAN UBUD
}

\author{
Ni Made Kansa Dewi Putri ${ }^{1}$ \\ Ni Luh Putri Srinadi ${ }^{2}$ \\ 1),2) Institut Teknologi dan Bisnis Stikom Bali \\ Surel: kansa@stikom-bali.ac.id
}

\begin{abstract}
The purpose of this study was to analyze the effect of management participation and user satisfaction on the effectiveness of using accounting information systems. This research was conducted in the LPD Sub-district of Ubud, using the observation method, interview method, the literature method, the documentation method, and the survey method by distributing questionnaires to LPD employees in the Sub-district of Ubud, with a population of 263 employees. Determination of the sample using non-probability sampling method with purposive sampling method. The research sample consisted of 87 employees. Data analysis uses Multiple Linear Regression. The results showed that management participation and user satisfaction had a positive and significant effect on the effectiveness of the use of accounting information systems in LPD in Ubud Gianyar, which means that the higher the management participation, the more effective the use of accounting information systems, vice versa and the higher the ability of satisfaction users will increase the effectiveness of using accounting information systems, and vice versa.
\end{abstract}

Keywords: management participation, satisfaction, accounting information system

\section{PENDAHULUAN}

Di era globalisasi saat ini,dengan adanya perubahan lingkungan yang pesat, dinamis, dan luas serta didukung oleh kemajuan teknologi informasi di segala bidang, mendorong transformasi masyarakat tradisional menjadi masyarakat informasi. Pemrosesan informasi berbasis komputer mulai dikenal orang dan hingga saat ini sudah banyak software yang dapat digunakan orang sebagai alat pengolah data untuk menghasilkan informasi. Teknologi informasi memungkinkan manusia untuk memperoleh informasi dari tempat yang berjauhan dalam waktu yang singkat dan dengan biaya yang murah. Selain itu teknologi informasi memunculkan suatu sistem yang bisa kita sebut sistem informasi.

Sistem informasi berperan dalam bidang akuntansi karena sistem pemrosesan informasi akuntansi berbasis komputer, banyak ditawarkan dengan tujuan untuk memberikan kemudahan bagi para akuntan untuk menghasilkan informasi yang dapat dipercaya, tepat waktu, lengkap, dapat dipahami, dan teruji. Sistem informasi akuntansi 


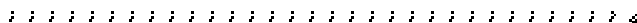

: Widya Akuntansi dan Keuangan

: Universitas Hindu Indonesia

Edisi Agustus 2020

dalam sebuah organisasi bisnis menjadi sarana penting untuk meningkatkan efisiensi organisasi dan mendukung daya saing perusahaan dengan menyediakan informasi keuangan dan akuntansi bagi manajemen (Alsarayreh et al., 2011).

Kemajuan teknologi informasi dan komunikasi telah membuat sistem informasi akuntansi menjadi suatu alat penting dalam dunia bisnis yang sangat kompetitif (Ogah, 2013 dalam Ratnaningsih, 2014). Penerapan sistem informasi akuntansi merupakan investasi yang penting untuk perusahaan. Penggunaan sistem informasi dapat meningkatkan daya saing perusahaan agar tidak tersisih dalam lingkungannya (Kustono, 2011).

Partisipasi Manajemen juga mempunyai peran yang penting dalam efektivitas penggunaan sistem informasi akuntansi. Partisipasi manajemen dapat mempengaruhi pengguna untuk mengembangkan perilaku positif yang akan meningkatkan efektivitas sistem (Ismail, 2009).

Menurut Gupta et al., (2007), kepuasan pengguna dalam penggunaan sistem informasi digunakan sebagai suatu ukuran efektivitas sistem informasi. Pengguna sistem informasi lebih dipengaruhi oleh staf sistem informasi dan pihak internal organisasi dibandingkan dengan pihak eksternal organisasi. Berdasarkan teori Technology Acceptance Model (TAM) bahwa kepuasan pengguna memiliki peran penting terhadap efektivitas penggunaan sistem informasi akuntansi. Dimana Kepuasan pengguna sangat penting untuk meningkatkan produktivitas, efisiensi, dan ketelitian pembuatan laporan organisasi.

Menurut Lembaga Pemerdayaan Lembaga Perkreditan Desa (LPLPD) Provinsi Bali (2014) Lembaga Perkreditan Desa merupakan salah satu lembaga keuangan yang telah menggunakan sistem informasi akuntansi dalam pengolahan data dan transaksinya. Berdasarkan Peraturan Daerah Bali No.4 Tahun 2012 LPD adalah salah satu unsur kelembagaan Desa Pakraman yang menjalankan fungsi keuangan Desa Pakraman untuk mengelola potensi keuangan Desa Pakraman. Berdasarkan data yang diperoleh, Kabupaten Gianyar dikelompokkan menjadi 2 Lembaga Pemerdayaan Lembaga Peerkreditan Desa (LPLPD) yaitu LPLPD Gianyar dan LPLPD Tegallalang. Dari data LPLPD Tegallalang, LPD Kecamatan Ubud terdiri dari 29 LPD. Lokasi penelitian pada LPD Kecamatan Ubud dipilih karena dari segi ekonomi masyarakat lebih cenderung bergerak dalam bidang perdagangan sehingga keberadaan LPD sangat diperlukan untuk membantu permodalan dalam usaha. Selain itu, perkembangan LPD di Kecamatan Ubud sangat berkembang maka sistem informasi akuntansi yang efektif sangat penting untuk meningkatkan pelayanan 


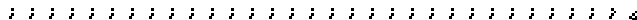

- Widya Akuntansi dan Keuangan

: Universitas Hindu Indonesia

Edisi Agustus 2020

kepada nasabah dan untuk pemproses data transaksi yang lebih cepat, akurat dan tepat waktu sehingga LPD di Kecamata Ubud mampu menghadapi persaingan yang telah cukup ketat.

Penelitian ini akan membahas tentang Partisipasi Manajemen, dan Kepuasan Pengguna terhadap Efektivitas Penggunaan Sistem Informasi Akuntansi. Adapun alasan yang mendasari bahwa penelitian ini perlu dilakukan adalah kondisi perkembangan menuntut lembaga keuangan terutama LPD untuk dapat memanfaatkan dukungan teknologi informasi dalam operasional usahanya. Selain itu kondisi persaingan yang semakin kompetetif dengan lembaga keuangan selain LPD seperti KSP dan Bank yang berkembang serta faktor- faktor individu yang berbeda mempengaruhi terjadinya kesalahan pengoperasian sistem informasi yang mengakibatkan penggunaan sistem informasi menjadi tidak efektif.

Partisipasi manajemen menurut Lesmana (2011) Partisipasi manajemen adalah dukungan yang diperlukan untuk memotivasi para pelaksananya. Tanpa partisipasi aktif akan dapat memberikan peluang bagi para pelaksana untuk mempermainkan sistem, bahkan mesipun manajemen puncak sudah cukup berpartisipasi dalam proses review dan pengesahan kadang-kadang masih ada manajer yang mencoba mencari lubang-lubang kelemahan.

Partisipasi manajemen diharapkan dapat membantu meningkatkan kinerja dan perilaku yang baik bagi karyawan. Pengendalian manajemen merupakan proses dimana manajer dapat mempengaruhi masing-masing anggota organisasi lainnya termasuk para bawahannya untuk mengimplementasikan sebuah strategi organisasi.

Menurut penelitian sebelumnya dari Christin (2017), menunjukan bahwa pengaruh kecanggihan teknologi informasi, partisipasi manajemen, budaya organisasi dan kepuasan pengguna berpengaruh positif terhadap efektivitas penggunaan sistem informasi akuntansi pada BPR kabupaten badung.

\section{H1 : Partisipasi Manajemen Berpengaruh Terhadap Efektivitas Penggunaan Sistem Informasi Akuntansi}

Tingkat kepuasan pengguna SIA adalah salah satu variabel yang banyak dipakai untuk menilai kesuksesan implementasi SIA pada suatu organisasi. Kepuasan menurut Kotler (2003) merupakan fungsi dari persepsi atau kesan atas kinerja atau hasil suatu produk dan harapan. Jika kinerja atau hasil suatu produk berada dibawah harapan maka pengguna 
ijisizis

: Widya Akuntansi dan Keuangan

: Universitas Hindu Indonesia

Edisi Agustus 2020

akan merasa tidak puas. Jika kinerja atau hasil suatu produk memenuhi harapan maka pengguna akan merasa puas. Jika kinerja atau hasil suatu produk melebihi harapan maka pelanggan akan sangat puas atau senang. Tingkat kepuasan pengguna aplikasi pelaporan keuangan pemerintah mengacu pada sejauh mana pengguna aplikasi merasakan aplikasi yang digunakan mampu memenuhi harapan mereka (Al-Adaileh, 2009).

Oleh karena itu penting bagi pengembang sistem informasi untuk mengetahui harapan para pemakai sistem informasi sehingga pada akhirnya mereka akan mencapai kepuasan dalam menggunakan sistem informasi. Untuk itu maka para pengguna hendaknya dilibatkan dalam pengembangan sistem.

\section{H2 : Kepuasan Pengguna Berpengaruh Terhadap Penggunaan Efektivitas Sistem Informasi Akuntansi}

\section{METODE PENELITIAN}

\section{Desain Penelitian}

Dalam penelitian ini akan menganalisis mengenai Pengaruh Partisipasi dan kepuasan Pengguna terhadap Efektivitas Penggunaan Sistem Informasi Akuntansi. Terdapat dua faktor yang dapat mempengaruhi sistem informasi akuntansi yaitu partisipasi manajemen dan kepuasan pengguna.

Partisipasi manajemen adalah kemampuan seseorang pemimpin menggunakan sumber daya secara efektif guna mencapai sasaran dengan melibatkat berbagai unsur yang terkait. Partisipasi manajemen diharapkan dapat membantu meningkatkan kinerja dan perilaku yang baik bagi karyawan.

Tingkat kepuasan pengguna SIA adalah salah satu variabel yang banyak dipakai untuk menilai kesuksesan implementasi SIA pada suatu organisasi. Kepuasan menurut merupakan fungsi dari persepsi atau kesan atas kinerja atau hasil suatu produk dan harapan. Jika kinerja atau hasil suatu produk berada dibawah harapan maka pengguna akan merasa tidak puas. Jika kinerja atau hasil suatu produk memenuhi harapan maka pengguna akan merasa puas. Jika kinerja atau hasil suatu produk melebihi harapan maka pelanggan akan sangat puas atau senang. 


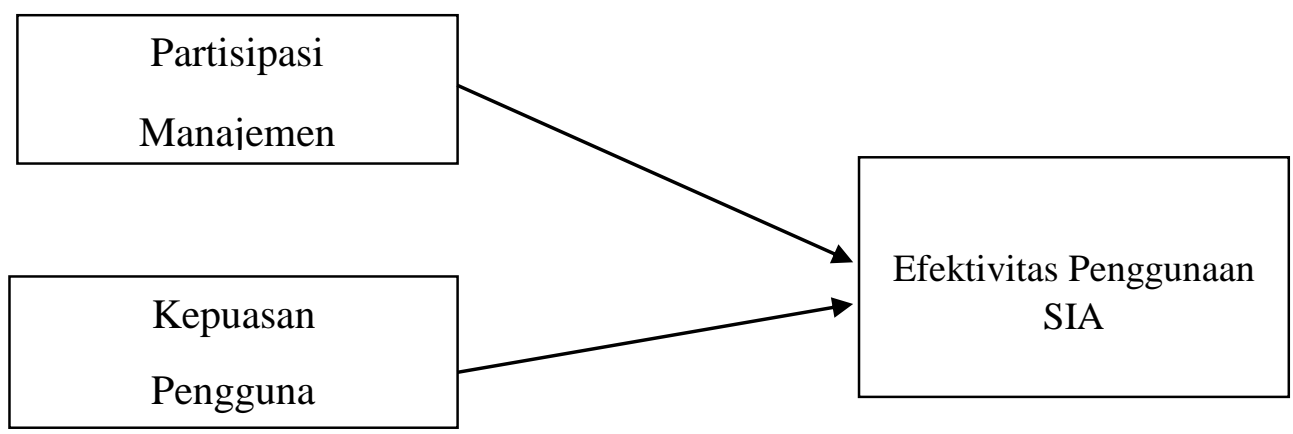

\section{Gambar 1. Kerangka Pemikiran}

Penelitian dilakukan di LPD Kecamatan Ubud Kabupaten Gianyar, Bali. Jenis data yang digunakan dalam penelitian ini adalah data Kualitatif dan data Kuantitatif sedangkan Sumber data yang digunakan dalam penelitian ini adalah data primer. Data primer meliputi observasi, hasil wawancara dan jawab kuesioner responden pada pegawai LPD yang menggunakan SIA. Teknik pengumpulan data yang digunakan dalam penelitian ini adalah Observasi, wawancara, Dokumentasi dan Kuesioner. Populasi dalam penelitian ini adalah seluruh LPD di Kecamatan Ubud yang yang terdaftar di LPLPD Tegallalang dimana Kabupaten Gianyar dikelompokan menjadi 2 Lembaga Pemerdayaan Lembaga Peerkreditan Desa (LPLPD) yaitu LPLPD Gianyar dan LPLPD Tegallalang yang berjumlah 29 LPD. Sampel dalam penelitian ini adalah semua pegawai bagian akuntansi dan keuangan yang bekerja pada LPD di Kecamatan Ubud sebanyak 87 orang responden, dengan berdasarkan kriteria sebagai berikut: (1) Seluruh LPD di Kecamatan Ubud yang terdaftar dan masih aktif di LPLPD Kabupaten Gianyar, (2) Kepala, kasir, dan staf karyawan bagian keuangan atau akuntansi yang berada pada LPD di Kecamatan Ubud.

\section{HASIL DAN PEMBAHASAN}

Pengujian hipotesis dilakukan untuk menguji hipotesis yang diajukan. Hipotesis yang diajukan dalam penelitian ini terkait variabel penelitian. Analisis regresi berganda dipilih untuk menganalisis pengujian hipotesis dalam penelitian ini. Berikut ini hasil analisis regresi berganda yang dilakukan dengan menggunakan program IBM SPSS Statistics 23.0. 


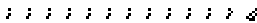

: Widya Akuntansi dan Keuangan

: Universitas Hindu Indonesia

Edisi Agustus 2020

Tabel 1. Hasil Uji Regresi Linear Berganda

Coefficients $^{\mathrm{a}}$

\begin{tabular}{|l|l|l|l|l|l|}
\hline \multicolumn{1}{|c|}{ Model } & \multicolumn{2}{|c|}{$\begin{array}{c}\text { Unstandardized } \\
\text { Coefficients }\end{array}$} & $\begin{array}{l}\text { Standardized } \\
\text { Coefficients }\end{array}$ & & Sig. \\
\cline { 2 - 4 } & $\mathrm{B}$ & Std. Error & Beta & & \\
\hline (Constant) & 1.532 & 1.889 & & .811 & .420 \\
$\mathrm{X} 1$ & .233 & .091 & .240 & 2.554 & .013 \\
$\mathrm{X} 2$ & .249 & .104 & .229 & 2.386 & .019 \\
\hline
\end{tabular}

\section{Sumber: Data diolah}

Dengan menggunakan Tabel 1 maka dapat diperoleh persamaan regresi linier berganda sebagai berikut.

Efektivitas pengguna SIA $(Y)=1,523+0,240\left(\mathrm{X}_{1}+0,229\left(\mathrm{X}_{2}\right)+\varepsilon \mathrm{i}\right.$

Berdasarkan hasil penelitian diketahui bahwa koefisien regresi sebesar 0,233, dengan nilai t sebesar 2,554 dan sig 0,013 < 0,05. Yang artinya partisipasi manajemen berpengaruh terhadap efektivitas penggunaan sistem informasi akuntansi. Hasil penelitian mengandung arti bahwa semakin tinggi partisipasi manajemen maka akan semakin meningkat efektivitas penggunaan sistem informasi akuntansi, begitu juga sebaliknya.

Partisipasi manajemen dapat mempengaruhi pengguna untuk mengembangkan perilaku positif yang akan meningkatkan efektivitas sistem (Ismail, 2009). Manajemen juga lebih mengetahui kebutuhan informasinya sehingga dapat memilih sistem yang sesuai dengan kebutuhan. Dengan demikian, sistem yang digunakan akan menjadi lebih efektif.

Hasil penelitian ini juga mendukung penelitian sebelumnya yang dilakukan oleh Christin (2017). Hasil penelitian menunjukan bahwa pengaruh partisipasi manajemen berpengaruh positif terhadap efektivitas penggunaan sistem informasi akuntansi pada BPR kabupaten badung. Berdasarakan pernyataan tersebut dapat ditarik kesimpulan bahwa partisipasi manajemen memiliki pengaruh terhadap efektivitas penggunaan sistem informasi akuntansi.

Berdasarkan hasil penelitian diketahui bahwa koefisien regresi sebesar 0,249, dengan nilai $\mathrm{t}$ sebesar 2,386 dan sig 0,019<0,05. Yang artinya kepuasan pengguna 


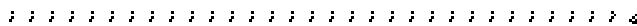

: Widya Akuntansi dan Keuangan

: Universitas Hindu Indonesia

Edisi Agustus 2020

berpengaruh terhadap efektivitas penggunaan sistem informasi akuntansi. Hasil penelitian mengandung arti bahwa semakin tinggi kepuasan pengguna maka akan semakin meningkat efektivitas penggunaan sistem informasi akuntansi, begitu juga sebaliknya.

Setianingsih dan Indriantoro (1998:87-88) menjelaskan bahwa Kepuasan Pengguna adalah seberapa jauh pengguna percaya pada sistem yang disediakan untuk memenuhi kebutuhan informasi mereka dan kualitas keputusan sebagai tujuan penting dari sistem informasi dalam mendukung pembuatan keputusan.

Hasil penelitian ini juga mendukung penelitian sebelumnya yang dilakukan oleh Shinta (2015). Hasil penelitian menunjukan bahwa Pengaruh Kepuasan Pengguna berpengaruh positif terhadap efektivitas Penggunaan Sistem Informasi Akuntansi pada LPD kecamatan seririt. Berdasarakan pernyataan tersebut disimpulkan bahwa kepuasan pengguna memiliki pengaruh terhadap efektivitas penggunaan sistem informasi akuntansi.

\section{KESIMPULAN DAN SARAN}

Berdasarkan hasil pembahasan penelitian dapat disimpulkan sebagai berikut: (1) Partisipasi Manajemen berpengaruh positif dan signifikan terhadap efektivitas penggunaan sistem informasi akuntansi di LPD Kecamatan Ubud. Maka partisipasi manajemen dapat mempengaruhi pengguna untuk mengembangkan prilaku positif yang akan meningkatkan efektivitas penggunaan sistem informasi akuntansi. (2) Kepuasan Pengguna berpengaruh positif dan signifikan terhadap efektivitas penggunaan sistem informasi akuntansi di LPD Kecamatan Ubud. Maka kepuasan pengguna akan meningkatkan efektivitas penggunaan sistem tersebut karena pengguna cenderung memanfaatkan sistem yang ada secara maksimal.

Berdasarkan pembahasan hasil penelitian, kesimpulan berikut beberapa saran yang dapat diberikan: (1) Hasil penelitian ini diharapkan dapat memberikan masukan terhadap pemilik perusahaan, dimana harus lebih memperhatikan partisipasi manajemen, dengan cara mengembangkan perilaku positif yang akan meningkatkan efektivitas sistem pada perusahaan. (2) Hasil penelitian ini diharapkan dapat memberikan masukan terhadap pemilik perusahaan, dimana harus lebih memperhatikan kepuasan pengguna, dengan cara meningkatkan produktivitas, efesiensi, dan ketelitian pembuatan laporan perusahaan. Jadi kesuksesan sistem informasi dalam perusahaan sejalan dengan kepuasan pengguna sistem informasi tersebut. 


\section{DAFTAR PUSTAKA}

Alsarayreh, M.N.O.A.A., Jawabreh, M.M.F. Jaradat, dan S.A Alamro. 2011. Technological Impacts on Effectiveness of Acccounting Information Systems (AIS) Applied by Aqaba Tourist Hotels. European Journal of Scientific Research. Vol 59. No. 3 : 361-369.

Irma Diana Putri. 2014. Pengaruh Kemampuan Teknik Personal, Program Pelatihan dan Pendidikan Pemakai, Insentif dan Partisipasi Manajemen pada Kinerja Penerapan Sistem Informasi Akuntansi. Skripsi. Jurusan Akuntansi Universitas Udayana.

Jogianto, H. (2011). Metodologi penelitian bisnis.Yogyakarta: BPFE

Komara, A. (2006). Analisis faktor-faktor yang mempengaruhi kinerja sistem informasi akuntansi. jurnal Maksi. Vol.6.

Kristiani,W. (2012). Analisis Pengaruh Efektivitas Teknologi Informasi Akuntansi Terhadap Kinerja Individual Pegawai PT. KIM ENG Sekuritas Indonesia, Jurusan Akuntansi, Fakultas Ekonomi Universitas Gunadarma.

Lesmana, Desy. 2011. Pengaruh Penganggaran Partisipatif, Sistem Pengukuran Kinerja dan Kompensasi Insentif terhadap Kinerja Manajerial Perguruan Tinggi Swasta di Palembang. Jurnal Ekonomi dan Informasi Akuntansi, 1(3), h: 238-252.

LPLPD Provinsi Bali. 2015. Pelatihan Standarisasi Karyawan LPD Kabupaten/ Kota se Bali.

Ratnaningsih, Kadek Indah dan Agung Suaryana, I Gusti Ngurah. 2014. Pengaruh Kecanggihan Teknologi Informasi, Partisipasi Manajemen, dan Pengetahuan Manajer Akuntansi Pada Efektivitas Sistem Informasi Akuntansi.E-Jurnal Akuntansi Universitas Udayana 6(1), h: 1-16.

Ratnaningsih, Kadek Indah., dan Agung Suaryana, I Gst. Ngurah. 2014. Pengaruh Kecanggihan Teknologi Informasi, Partisipasi Manajemen, Dan Pengetahuan Manajer Akuntansi Pada Efektivitas Sistem Informasi Akuntansi. E- Jurnal Akuntansi Universitas Udayana, 6(1): h: 1-16.

Wigyaringtyas, Tuning Mey. 2014. Analisis Faktor-Faktor yang Mempengaruhi Minat Penggunaan Sistem Informasi Terkomputerisasi (Studi pada KSP di Kab. Semarang). Dissertasi. Program Studi Akuntansi Fakultas Ekonomi dan Bisnis Universitas Kristen Satya Wacana.

Wilayanti, Ni Wayan., Dharmadiaksa IB. 2016. Keterlibatan dan Kemampuan Teknik Personal Pada Efektivitas Penggunaan Sistem Informasi Akuntansi. E-Jurnal Akuntansi Universitas Udayana, 15(2): h: 1310-1337. 